\title{
CASPASE-3 and FAS-L expression and their roles as signal transduction in hepatocellular carcinoma
}

\author{
Soha M Hamdy, Saad M El-Gendy and Sahar S.Atrees
}

Science faculty, chemistry department, Fayoum University

\section{ABSTRACT}

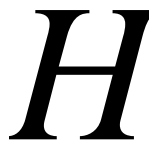

Tepatocellular carcinoma (HCC) is a common malignant affecting approximately-one million of people around the world every year. This study aimed to early recognition of the carcinogenic effect of $\mathrm{N}$ nitrosodiethlyamine (NDEA) on hepatocytes and expression of Fas-L and Caspase3. The study was done using tissue homogenate of 60 male albino rats divided into 2 groups: group 1,control group (30 rats) and Group 2, -N-nitrosodiethylamine (NDEA) treated group (NDEA, in a single dose $200 \mathrm{mg} / \mathrm{Kg}$ wt and; Carbon tetrachloride (CCL4), twice per week $3 \mathrm{ml} / \mathrm{Kg}$ wt) (30 rats). 10 rats from each control and treated group were sacrificed at the $1^{\text {st }}, 2^{n}$, and $3^{\text {rd }}$ months of the treatment for evaluation (1) of glutathione $s$ transferase(GST), glutathione peroxidase (GPX), glutathione reductase (GRase), glutathione reduced form (GSH), superoxide dismutase (SOD) levels, (2) studying expression of Fas-L and Caspase-3 and (3) for histopathological examination. The results revealed that the treated group antioxidant enzymes levels (Glutathione family and SOD) showed a significant decrease with gradual rates through the three months of the treated compared to the control group, whereas the GRase level was significantly increased compared to the control group. Caspase-3 and Fas-L in liver tissue homogenate in the treated group was significantly decreased in comparison with the control group. The histopathological results showed pronounced changes with evident fatty degeneration (steatosis), marked microvascular steatosis with malignant hepatocytes amounting grade 1. Finally, study can conclude that investigation of liver tissue markers induced by the chemical carcinogen NDEA at different stages of the development of cancer could help in getting more information about the development of HCC and more investigated studies on Caspase-3 and Fas-L, could be a promising way for the treatment of $\mathrm{HCC}$.

Key wards: CASPASE-3 - FAS-L expression- hepatocellular carcinoma 


\section{INTRODUCTION}

Hepatocellular carcinoma (HCC) is a common malignancy affecting approximately one million of people around the world every year. It represents the fifth most common cancer worldwide with an incidence equal to the death rate (Marrero and Pelletier, 2006). The incidence of HCC is low in the occidental world and high in Southeast Asia and sub-Saharn Africa. However, it has been rising during the last two decades in Europe, United States and Japan (Motola,et al,2006). HCC primarily affects old people, reaching its highest prevalence among those aged 65 to 69 years old. Chronic infection by viral $B$ hepatitis $\mathrm{HBV}$ is the most common cause of this neoplasm. Other important causes are cirrhosis, chronic viral hepatitis (hepatitis $\mathrm{C}$ virus, and hepatitisB plus D viruses), alcohol abuse, obesity and toxins. The nitrosamine and various other $\mathrm{N}$-nitroso compounds, form a large group of typically genotoxic carcinogens (Magee and Barnes1967; Preussman et al, 1984). Nitrosamines have been found to be carcinogenic in over 40 animal species and one or more of the compounds has induced tumors in almost every organ in rodents. The carcinogenic $\mathrm{N}-$ nitrosodiethylamine (NDEA), one of the previous compounds, is one of the main point of interest in this study. The second point of the interest is the expression of Fas-L and caspase-3. The Fas-Fas ligand (Fas-L) system is recognized as a major pathway for the induction of apoptosis in cells and tissues (Nagata, 1997). Fas-L has recently been detected in many types of cancer, including astrocytoma's (Saaa et al., 1997), colon cancer (Oconnell et al, 1996), basal cell carcinomas (Arai et al, 1997), melanoma (Hahne et al, 1996), and lung cancer (Nehans et al, 1997). Tumor necrosis factor (TNF) - related apoptosis - inducing ligand (TRAIL) is known as a major mediator of acquired immune tumor surveillance, and is currently being tested in clinical trials as a novel cancer therapy (Mucha et al, 2009). 
Many caspase substrates have been identified, only a few have been clearly demonstrated to play defined roles in the apoptotic process. Fas-L ligates to its receptor, Fas, resulting in upstream activation of caspase-8, which may intern mediate cytochrome-c release. Cytochrome-c release may also function as an amplification loop to potentiate the effects of caspase-3.

One approach that has been promising results in many tumors is immunotherapy (Greten and Jaffee, 1999). Also in HCC, several different studies suggest that immunotherapeutic approaches will be successful for the treatment of this disease. So, aim of work was to study expression of Fas-L and caspase- 3 and their roles with antioxidant enzymes.

\section{Materials and Methods}

Materials:

- Chemicals.

$\mathrm{N}-$ nitrosoamine, carbon tetra chloride, 5, 5 dithiobis nitrobenzoic acid) (DTNB), phenazine methosulphate (PMS),
Nicotineamide adenine dinucleotid phosphate hydrogen (NADPH), glutathione oxidized form (GSSG) ,glutathione reduced (GSH), ethylene diamine tetraacetic acid (EDTA), formalin, potassium phosphate, sulfosulcylic acid were obtained from Sigma, Aldrich.

- Kits, for caspase provided from BioSourceinternational, Ine, USA, caspase3/Cpp32, and for Fas-L ligand from Diaclone, USR, UKAS (producer No .043-A).

- The animals were obtained from National Cancer Institute, Cairo University.

- Diet, The standard diet prepared as described by Reeves et al. (1993),

Methods:

The experiment was designed on 60 waster albino male rats weighing 165 $\pm 15 \mathrm{~g}$. The rats were divided into 2 groups (30 rats each).Group 1 - normal healthy control (30 
rats), and group 2- Nnitrosodiethylamine (NDEA) treated group (30 rats), 200 $\mathrm{mg} / \mathrm{Kg}$ wt NDEA was injected intraperitonean as a single dose then after two weeks the rats received $3 \mathrm{ml} / \mathrm{Kg}$ wt (CCI4)in oil twice per week until the end The animals were housed in cages. All were fed with a normal standard, diet and tap water during the total period of the experiment.

\section{Liver tissues preparation,}

A small piece of each liver (normal and treated) was stored in $10 \%$ neutral formaline for 24 hours, for histopathological examination. Tissue specimens were washed in running tap water for 15 hours, dehydrated in standard alcoholic series 50, 70, and $95 \%$, and then cleared in xylene before embedding in paraffin wax. Samples were then sectioned 4-6 micron thickness and stained with the usual haematoxylin and eosin method (Scheuerand Chalk, 1986) .Half of gram of each liver (normal and treated) was dissected, washed with saline and homogenates in $2 \mathrm{ml}$ of $0.1 \mathrm{M}$ phosphate buffer $\mathrm{pH} 7.4$ of the experiment. 10 rats from each control and treated group were sacrificed under anesthesia after the $1^{\text {st }}, 2^{\text {nd }}$, and $3^{\text {rd }}$ months of the treatment for the biochemical, molecular and histopathological studies.

for all biochemical assays except assays for reduced glutathione, the liver tissues were homogenated in $1 \mathrm{ml} 0.1 \mathrm{M}$ phosphate buffer $\mathrm{pH} 7.4$ plus $1 \mathrm{ml}(4 \%)$ sulfosalcylic acid to precipitate the proteins. The prepared homogenates for all assays, were kept at $-20 \mathrm{C}^{\circ}$ until used.

Glutathione reduced (GSH) and GST were measured according to (Jakoby, 1985), Glutathione peroxidase (GPx) was estimated according to (Paglia and Valentine, 1976), the Specific activity of GPx was expressed in units per milligram of protein and the standard curve protein concentration was determined as described by Bradford (1976), Glutathione Reductase (GRase) was measured as described by Carberg and Mannervick (1985), Superoxide dismutase 
(SOD) was assayed as Dwivedi and Partap, (1986).

\section{Caspase assay}

Caspase -3 was made using the DEVD Asparate- glutamatevaline- aspartate (substrate of

\section{Results \& discussion}

The antioxidant enzymes GSH, GST, and Gpx mean \pm S.D levels showed a significant decrease in all treated group through period compared with their control mean values, (table .1). GSH showed a nonsignificant decrease in first month, but the second and third months showed decrease in its levels table .1.

As it was known, the first phase of chemical carcinogenesis are often characterized by intracellular production of superoxide anion radicals or peroxides ( Little et al , 1983;Oberly et al ,1984), which are free radicals or generate of free radicals. It was known that these free radicals were responsible of neoplastic phenotype damage DNA (Emerit and Cerutti, 1981; Birnbiom, 1982). The nitrosoamines, the carcinogen caspase) kit were determined by Casciolo et al, (1996), Fas/ Fas ligand was determined by FasL kit according to Talania et al, (1997).

agent, in this study has a great effect on super family microtonal mixed function oxidizes (Swenberg et al, 1991), and this was observed in most antioxidant enzymes measured. GSH depletion results was confirmed by Dhanasekaran et al (2008), who concluded that the animals treated with NDEA showed a decrease in activity of detoxication enzyme as GSH and other liver markers. These results reflected the disturbance in function of hepatocytes was duo to decrease in GSH especially in the last stages of treatment. This agreed with a recent study by Jakovljevic et al, (2009).

The reduced level of GST using NEDA as hepatocarcinogen and $\mathrm{CCL}_{4}$ as a promoter agreed with results study of Nishimura et al, (2008), who used fenofibrate to induce hepatocarcinogenesis in rats after NDEA initiation. 
Also Subramanian et al, (2008) confirmed the decrease in GST level. On the other hand, study by Wang et al, (2009) who used high fat -diet as promoter for NDEA in hepatocarcinogen in rats ,found that GST level was elevated ,this may indicate a specific pathway for high fat diet to increase GST level . However this point must be discussed in depth to get full information about GST level and initiation of hepatocarcinogenesis.

G Px activity showed a significant decrease by nearly constant rate through all the three months period of treatment, this was supported by finding of previous studies on NDEA on hepatocarcinogenesis made by Ramakrishnan et al, (2006). Also, Dhanansekaran et al, (2008), and Jakovljeviv, et al (2009), confirmed GPx ranged level from promoter or inhibition for NDEA and study its effect on liver tumor will be promising as new biomarker .

In contrast to other glutathione family GRase mean \pm S.D level showed a significant increase in all treated group (table .2.), this was supported by Jakovljevic et al, (2009) who concluded that GRase activity increased in NDEA induced hepatomas, this significant increase of GRase may be directly correlated to hi $\checkmark$ gh GRase protein content of cancer cell as bovine leukemia virus transformed fibroblast, there for disequilibrium of delicate oxidant versus antioxidant balance moved towards an oxidative side as partly demonstrated by dramatic loss of glutathione synthesize (GS) activity.

Liver SOD mean level showed a non-significant change, only a slight decrease observed in last stage of experiment table.2.

The correlation study between antioxidant enzymes, showed a negative correlation between glutathione $-\mathrm{S}$ transferase and $\mathrm{SOD}(\mathrm{r}=-0.646, \mathrm{p}=0.05)$ Fig.1. Also, a negative correlation between glutathione -Stransferase and glutathione reductase $\left(\mathrm{r}=-0.792 \mathrm{P}=\begin{array}{ll}0 & .01\end{array}\right)$ Fig.2., also SOD was correlated negatively with GPx with $P$ 0.05 .

Fas- L and caspase expression: 
Fas-L mean level, which was determined in the three month varied between a nonsignificant change in early stage of treatment to a significant decrease in liver Fas-L in last stages of treatment ( $\mathrm{P}$ values $0.7,0.03$ and 0.009 respectively) table. 2.

Caspase activity was determined using three different concentration of liver tissue homogenate of each animal (25 ug, $50 \mathrm{ug}$, 100ug protein) to determine caspase activity during the period of the treatment using the average OD values of caspase -3 at three different protein concentration, data curve in Fig.3. ,represented the expression of caspase -3 during the three months of treatment, the curve showed down expression of caspase -3

Furthermore, it was proved that the increased serum soluble Fas (s Fas) in HCV patients is accompanied by down regulation of Fas / Fas L expression resulting in inhibition of apoptosis in liver cells (Xia et al, 2001). However, other study emphasized that Fas in when compared to the normal control group.

Human hepatocellular carcinoma (HCC) appeared to be strongly associated with apoptosis and its breakdown may be involved in the occurrence of HCC. Like Fas /Fas L, the tumor necrosis factor (TNF) -related apoptosis -inducing ligand (TRAIL) transduces apoptosis in a number of cancers; it is also candidate for cancer therapy (Yano et al, 2003). In this study the dramatically decreased level in both Fas / Fas L and caspase -3 at the end of the treatment, were confirmed by the previous study of Lee, et al (2001), who demonstrated that all HCCs showed one or more alterations of the Fas pathway molecules known to inhibit Fas mediated apoptosis.

hepatocytes showed strong expression and Fas-L also showed intensive expression in infiltrating lymphocytes and scattering hepatocytes, so the apoptosis caused by Fas might be one of the important pathogenesis of hepatitis gravis. Also, the decrease in caspase -3 expression was 
confirmed by Yano et al (2003), who concluded that caspase -3 activity and TRAIL- R1, R2 expression in tumor tissues were significantly lower than those in non-tumor tissue in HCB related HCC, however, some HCV-related HCC cases, demonstrated elevated caspase -3 activity and TRAIL - R1, R2 expression in tumor tissues. In this study a significant positive correlation between Fas-L and both GST and SOD enzymes mean level was found $(\mathrm{r}=0.912, \mathrm{P}$ values 0.001 and 0.01 respectively) Fig.4

The decrease in caspase-3, may contribute to cirrhotic nodules related to HCC that appeared at the third month of the treatment. This was in agreement with Caillot, et al (2009), they reported that tumor suppression activated pathway-6 (TSAP6) that transcript codes for a transmembrane molecule which is an inducer of a caspase -3 dependent apoptotic pathways, could reflect a decrease in the apoptotic process. Whereas Lu, et al (2008) found that the increased expression of caspase-3 in the transfected Hep G2 cells provided feasible evolution of the treatment of the primary liver cancer. Moreover, activation of caspase -3 and subsequent apoptosis by 5flurouracil (5 $\quad-F U)$ and Andrographolide (ANDRO) which is a natural bicyclic diterpenoid lactone that was isolated from Andrographispaniculata, and has been shown to suppress the growth of HCC cells and to trigger apoptosis in vitro. This might be effective in the treatment of HCC cells SMMC-7721. In present study the combination of $\mathrm{CC}_{4}$ and NDEA induced HCC via the decrease level of the antioxidant enzymes and inhibition of caspase -3. Also Takashima, et al (2008), had studied the mechanism of di(2-ethylhexyl)- phthalate (DEHP) for inducing hepatocarcinogenes is via suppression "of G2/ M arrest that was regulated by Gadd45a and caspase 3- dependent apoptosis in peroxisome proliferator activated receptor alpha (Pparaipha) null mice. However these genes may not be involved in tumorigenesis in the wild type mice.

\section{Histopathological results:}

The histopathological results for the control group (C) showed 
normal pattern of hepatocytic liver architecture (Fig 5).The histopathological results for treated groups showed Cirrhotic nodules and moderate portal chronic inflammatory infiltrate with interface hepatitis was shown after first and second treatment months (Fig.6). After the third month the histopathology further showed pronounced changes with evident fatty degeneration (steatosis), marked microvascular steatosis with malignant hepatocyte amounting grade 1 HCC, (Fig.7).

\section{References}

Arai H; Gordon D; Nabel EG and Nabel GJ (1997):

Gene transfer of Fas-L induces s tumor regression in vivo. Proc. Natl. Acad.

Sci. USA, 94:1386213867.

Birnboim, H. C. (1982):

DNA strand breakage in human leukocytes exposed to a tumor promoter, phorbolmyristate acetate .Science. 215:1247-1249.

Boitier, E; Bouda MM; Guillouzo CG; Defer N; Picot

\section{CONCLUSION:}

Finally, we can conclude that investigation of liver tissue markers by chemical carcinogen NDEA at different stages of the development of cancer could help in getting more information about the development of HCC. More immunotherapy of studies on Caspase- 3 and Fas-L, could be a promising way for the treatment of HCC.

IC; Letoux JP and Marsac C (1995):

Impairment of the mitochondrial respiratory chain activity in diethyl nitrosoamine- induced rat hepatomas: possible involvement of oxygen free radicals. Cancer Research .55. 3028-3035.

Casciola-Rosen L; Nicholson DW; Chong T; Rowan KR; Thornberry NA; Miller DK; Rosen A. (1996):

Apopain, CPP32 cleaves proteins that are essential to cellular repair: a

Bulletin of the National Nutrition Institute of the Arab Republic of Egypt. June 2018 (51) 9 
fundamental principle of apoptotic deathm J. Exp. Med.183 (5): 1957-1964.

Caillot, Carberg I and mannervick B (1985):

Glutamate, glutamine, glutathione, and related compounds in methods in enzymology. Minister A (ed).academic press. Inc. Vol. 113, pp.484-485

\section{Connoll O J; Sullivan O G C;} Collins JK and Shanahan F (1996):

The fas counter attack: Fas mediated. $\mathrm{T}$ cell killing by colon cells expressions Fasligand. J. Exp. Med. 184:1075-1082.

\section{Dwivedi RS and Partap VB} (1986):

Role of lipid peroxidation and trace metal in cataractogenesis. Indian .J. Ophthamol.34:45-51.

Dhanasekaran M; Basker AA; Ignacimuthu S; Agastian $P$ and Duraipandiyan V (2008):

Chemopreventive potential of Epoxy clerodane diterpene from Tinospora cordifolia against diethylnitrosamine-induced hepatocellular carcinoma, Invest New Drugs; 27(4):347-55.

\section{Emerit I and Cerutti PA (1981):}

Tumor promoter phorbol 12- myristate -13- acetate induces chromosomal damage via indirect action .Nature 293:144-146.

Greten TV and Jaffee, EM (1999):

Cancer Vaccines, J. Clin.

Oncol. 17: 1047-1060

\section{Hane M; Rimoldi D; Schroter M et al. (1996): \\ Melanomma cell expression on Fas (Apo- 1/CD95) ligand: Science .274: 1363-1366.}

\section{Jakoby W B (1985):}

Glutamate, glutamine, glutathione, and related compounds .In methods in enzymology. Meister A (ed). Academic press.Inc. Vol 113,pp .500-501.

Jakovljevic V, Popovic M, Raskovic A, Sabo A, Horvat O, Mitic R, Vasic R (2009): 
"Effect of aroma and magnum hops extracts and paracetamol on antioxidant liver parameters in mice". Eur J Drug Metab Pharmacokinet; 34 (1): 37- 41.

Little JB; Kennedy AR, and Nagasawa H (1983):

Involvement of free radical intermediates in oncogenic transformation and tumor promotion in vitro .inradioprotectors and anticarcinogens. Academic press, New York, pp.487493.

Lee SH1; Shin MS; Lee HS; Bae JH; Lee HK; Kim HS; Kim SY; Jang JJ; Joo M; Kang YK; Park WS; Park JY; Oh RR; Han SY; Lee JH; Kim SH; Lee JY and Yoo NJ (2001):

Experssion of Fas and Fas related molecules in human hepatocellular carcinoma. Human Pathology, 32: (3) 250-256

Lu Y; Wu LQ; Wang SG; Lv ZH and Han B (2008):

Clin Chem Lab Med .46(4): 470-4.
Magee PN; and Barnes JM (1967):

Carcinogenic nitroso compound. Adv. Cancer.

Res. 10:163-246.

Marrero JA and Pelletier S (2006):

Hepatocellular carcinoma, Clin.Liver.Dis.10 (2): 33951.

Motolo Kuba D; Zamora Valdes D; Uribe $M$ and MendezSanchez N (2006):

Hepatocellular carcinoma. An overview, Ann. Hepatol. 5: 16-24.

Nagata S (1997):

Apoptosis by death factor, Cell, pp.88:355-365.

Niehans GA; Brunner T; Frizelle SP Liston JC, Salerno CT, Knapp DJ, Green DR, Kratzke RA (1997):

Human lung cancinoma express Fas ligand. Cancer Res.15: 57: 1007-1012.

Nishimura J; Dewa Y; Okamura T; Muguruma M; Jin M; Saegusa Y; Umemura $T$ and Mitsumori K (2008):

Possible involvement of oxidative stree in fen 
fibrate - induced

hepatocellular in rat,

Arch.Oxicol.82 (9): 641-

54.

\section{Oberly LW and Oberly TD} (1984):

The role of superoxide dismutase and gene amplification in carcinogenesis, J. Thor Biol. 106p:403-422.

Paglia DE and Valentine WN (1967):

Studies on the quantitative and qualitative characterization of erythrocyte glutathione peroxidase, J. Lab .Clin Med. Vol 70 (1): 158-169

\section{Preussman R; and Stewart BW} (1984):

$\mathrm{N}$ - Nitrous carcinogens in C.E. Searle (ed). Chemical carcinogens, Washington DC, American chemical society, ACS Monograph 182, vol., 2, Ed.2, pp.643828.

Saa P; Walker PR; Hahne M; Quiquerez AL; Schnuriger V; Perrin G; French L; Van Meir EG; de Tribolet
N; Tschopp J and Dietrich P Y (1997):

Fas ligand expression by astrocytoma in vivo: maintaining immune privilege in the brain. $J$. Clin invest.99:1173-1178.

\section{Scheuer PJ and Chalk BT (1986): \\ Clinical tests of histopathology. Wolf .Med. Publ.Ltd.( London). 84-85.}

Subramanian P, Dakshayani KB, Pandi-Perumal SR, Trakht I, Cardinali DP(2008):

24-hour rhythms in oxidative stress during hepatocarcinogenesis in rats: effect of melatonin or alpha-ketoglutarate, Redox Rep. 13:78-86.

Swenberg JA; Hoel DG and Magee PN (1991):

Mechanistic and statistical insight into the larg carcinogenesis bioassays on $\mathrm{n}$ - nitrosodiethyle amine and Nnitrosomethyl amine Cancer research.51: 64096414. 
Takashima K; Ito Y; Gonzalez FZ and Nakajima $T(2008)$ :

$J$ Occup Health. 46(4): 470-4

Talanian RV; Quinlan C; Trautz S; Hackett MC; Mankovich JA; Banach D; Ghayur T; Brady KD and Wong WW. (1997):

Substrate specificities of caspase family protease, $\mathrm{J}$. Biol. Chem.272: 96779682.

\section{Thirunavukkarasu C;}

Premkumar K; Sheriff A K and Sakthisekaran D (2008):

Sodium selenite enhances glutathione peroxidase activity and DNA strand breaks in hepatoma induced by Nnitrosodiethylamine and promoted by phenobarbital. Mol Cell Biochem. 310 (1-2): 12939.

Ramakrishnan

Raghavendran

Vinodkumar $R$ and Devaki $T$ (2006):

Suppression of N- diethyl nitrosoamine induced hepatocarcinogenesis by silymarin in rats, chemicobiological interaction s. 161: 104-114.

Wang Y; Ausman LM and et al. (2009):

Non alcofolic steatohepatitis induced by a high -fat diet promoters diethyl nitrosamine induced early hepatocarcinogenesis in rat Int J. Cancer. 1: 124 (3).540-6

Xia Q; Shi S (2001):

J. Tonji Med. Uni .21(2):112-4.

\section{Yang L; Wu D; Luo K; Wu P (2009):}

Andrographolide enhances 5-fluorouracil-induced apoptosis via caspase-8dependent mitochondrial pathway involving p53 participation in hepatocellular carcinoma (SMMC-7721) cells. CancerLett.18:276(2):1808. 
Table 1:the mean \pm S.D. values for G SH, GST, in all period of the treatment

\begin{tabular}{|c|c|c|c|c|c|c|c|c|c|}
\hline \multirow[b]{3}{*}{ Group N (10) } & \multicolumn{9}{|c|}{ Mean \pm S.D, \pm S.E,$P$ values } \\
\hline & \multicolumn{3}{|c|}{$1^{\text {st }}$ month } & \multicolumn{3}{|c|}{$2^{\text {nd }}$ month } & \multicolumn{3}{|c|}{$3^{\text {rd }}$ month } \\
\hline & $\begin{array}{c}\text { Control } \\
\text { Group } \mathrm{C}_{1}\end{array}$ & $\begin{array}{c}\text { Treated } \\
\text { Group } \\
\mathrm{T}_{1}\end{array}$ & $\begin{array}{c}\boldsymbol{P} \\
\text { value }\end{array}$ & $\begin{array}{c}\text { Contro } \\
1 \\
\text { Group } \\
\mathrm{C}_{2}\end{array}$ & $\begin{array}{c}\text { Treated } \\
\text { Group } \\
\mathrm{T}_{2}\end{array}$ & $\boldsymbol{P}$ value & $\begin{array}{c}\text { Control } \\
\text { Group } \mathrm{C}_{3}\end{array}$ & $\begin{array}{c}\text { Treated } \\
\text { Group } T_{3}\end{array}$ & $\boldsymbol{P}$ value \\
\hline $\begin{array}{c}\mathrm{GSH} \\
\mathrm{mg} / \mathrm{g} \text { tissue }\end{array}$ & \multirow[t]{2}{*}{$\begin{array}{c}2.377 \pm \\
0.79\end{array}$} & \multirow[t]{2}{*}{$\begin{array}{c}2.426 \pm \\
1.16\end{array}$} & \multirow{2}{*}{0.913} & \multirow{2}{*}{$\begin{array}{c}2.506 \pm \\
0.71\end{array}$} & $\begin{array}{c}1.574 \pm \\
0.67\end{array}$ & \multirow{2}{*}{0.008} & $2.36 \pm 0.89$ & $\begin{array}{c}1.53 \pm \\
0.44\end{array}$ & \multirow{2}{*}{0.016} \\
\hline$* P, * * P$ & & & & & $\begin{array}{c}* p \\
=0.048\end{array}$ & & $* p=0.034$ & $* * p=0.863$ & \\
\hline $\begin{array}{c}\text { GST } \\
\mathrm{Nmol} / \mathrm{min} / \mathrm{mg}\end{array}$ & \multirow[t]{3}{*}{$\begin{array}{l}48.8 \pm \\
11.87\end{array}$} & \multirow[t]{3}{*}{$\begin{array}{c}37 \pm \\
15.68\end{array}$} & \multirow{3}{*}{0.07} & \multirow{3}{*}{$\begin{array}{c}42.8 \pm \\
13.0\end{array}$} & $\begin{array}{c}14.2 \pm \\
9.22\end{array}$ & \multirow{3}{*}{$\mathrm{P}<0.001$} & $\begin{array}{c}42.2 \pm \\
12.1\end{array}$ & $\begin{array}{c}15.4 \pm \\
11.3\end{array}$ & \multirow{3}{*}{$<0.001$} \\
\hline & & & & & & & & & \\
\hline$* P, * * P$ & & & & & $\begin{array}{c}* p<0.00 \\
1\end{array}$ & & $*_{p}=0.002$ & $* * p=0.7$ & \\
\hline $\begin{array}{c}\text { GPX } \\
\text { Nmol/min/mg }\end{array}$ & \multirow[t]{2}{*}{$\begin{array}{c}67.16 \pm \\
37.2\end{array}$} & \multirow[t]{2}{*}{$\begin{array}{c}50.81 \pm \\
17.1\end{array}$} & \multirow[t]{2}{*}{0.06} & \multirow{2}{*}{$\begin{array}{c}83.92 \pm \\
26.2\end{array}$} & $\begin{array}{c}51.53 \pm \\
15.1\end{array}$ & \multirow[t]{2}{*}{0.003} & $\begin{array}{c}77.87 \pm \\
30.8\end{array}$ & $\begin{array}{c}51.5 \pm \\
17.4\end{array}$ & \multirow[t]{2}{*}{0.03} \\
\hline$* P, * * P$ & & & & & $* p=0.9$ & & $* p=0.9$ & $* * p=0.9$ & \\
\hline
\end{tabular}

C:control animals, T: treated animals, $1,2,3$ are the period of scarifying animals /months

$\mathrm{P} \leq 0.05$ was considering significant, $\mathrm{P}$ for value versus control, * $p$ for versus between $\mathrm{T} 1, \mathrm{~T} 2$,

$* * p$ for versus between $\mathrm{T} 2, \mathrm{~T} 3$. 
Table 2: the mean \pm S.D. values for GRase,SOD, Fas-L after all the three months treated period

\begin{tabular}{|c|c|c|c|c|c|c|c|c|c|}
\hline \multirow[b]{3}{*}{ Group N (10) } & \multicolumn{9}{|c|}{ Mean \pm S.D , \pm S.E, P values } \\
\hline & \multicolumn{3}{|c|}{$1^{\text {st }}$ month } & \multicolumn{3}{|c|}{$2^{\text {nd }}$ month } & \multicolumn{3}{|c|}{$3^{\text {rd }}$ month } \\
\hline & $\begin{array}{c}\text { Control } \\
\text { Group } \mathrm{C}_{1}\end{array}$ & $\begin{array}{c}\text { Treated } \\
\text { Group } \\
\mathrm{T}_{1}\end{array}$ & $P$ value & $\begin{array}{c}\text { Control } \\
\text { Group } \\
\mathrm{C}_{2}\end{array}$ & $\begin{array}{c}\text { Treated } \\
\text { Group } \\
\mathrm{T}_{2}\end{array}$ & $P$ value & $\begin{array}{c}\text { Control } \\
\text { Group } \mathrm{C}_{3}\end{array}$ & $\begin{array}{c}\text { Treated } \\
\text { Group } \mathrm{T}_{3}\end{array}$ & $P$ value \\
\hline $\begin{array}{c}\text { GRase } \\
\mathrm{Nmol} / \mathrm{min} / \mathrm{mg}\end{array}$ & \multirow{2}{*}{$\begin{array}{c}22.05 \pm \\
9.52\end{array}$} & \multirow[t]{2}{*}{$\begin{array}{c}67.86 \pm \\
35.64\end{array}$} & \multirow[t]{2}{*}{$\mathrm{P}<0.001$} & \multirow[t]{2}{*}{$\begin{array}{c}21.55 \pm \\
9.22\end{array}$} & $\begin{array}{c}85.38 \pm \\
24.5\end{array}$ & \multirow[t]{2}{*}{$\begin{array}{c}\mathrm{P}<0.00 \\
1\end{array}$} & $\begin{array}{c}24.61 \pm \\
9.8\end{array}$ & $\begin{array}{c}44.78 \pm \\
19.4\end{array}$ & \multirow[t]{2}{*}{$\mathrm{P}=0.008$} \\
\hline$* P, * * P$ & & & & & $*_{p}=0.2$ & & $* p=0.08$ & $* * p<0.001$ & \\
\hline $\begin{array}{c}\mathrm{SOD} \\
\mathrm{Nmol} / \mathrm{min} / \mathrm{mg}\end{array}$ & \multirow{2}{*}{$\begin{array}{c}2.606 \pm \\
1.8\end{array}$} & \multirow{2}{*}{$\begin{array}{c}2.264 \pm \\
1.23\end{array}$} & \multirow[t]{2}{*}{$\mathrm{P}=0.6$} & \multirow{2}{*}{$\begin{array}{c}3.529 \pm \\
1.45\end{array}$} & $\begin{array}{c}2.826 \pm \\
1.53\end{array}$ & \multirow[t]{2}{*}{$\mathrm{P}=0.3$} & $\begin{array}{c}3.064 \pm \\
1.88\end{array}$ & $\begin{array}{c}1.504 \pm \\
0.96\end{array}$ & \multirow[t]{2}{*}{$\mathrm{P}=0.03$} \\
\hline$* P, * * P$ & & & & & $* p=0.3$ & & $* p=0.1$ & $* * p=0.03$ & \\
\hline Fas-L & \multirow[t]{2}{*}{$\begin{array}{c}1.147 \pm 0 . \\
52\end{array}$} & \multirow[t]{2}{*}{$\begin{array}{c}1.08 \pm 0 . \\
47\end{array}$} & \multirow[t]{2}{*}{$\mathrm{P}=0.7$} & \multirow[t]{2}{*}{$\begin{array}{c}1.214 \pm \\
0.52\end{array}$} & $\begin{array}{c}0.728 \pm \\
0.33\end{array}$ & \multirow[t]{2}{*}{$\mathrm{P}=0.01$} & $\begin{array}{c}1.075 \pm \\
0.33\end{array}$ & $\begin{array}{c}0.609 \pm \\
0.195\end{array}$ & \multirow[t]{2}{*}{$\mathrm{P}=0.0011$} \\
\hline$* P, * * P$ & & & & & $\begin{array}{c}* p \\
=0.039\end{array}$ & & $\begin{array}{c}* p \\
=0.0091\end{array}$ & $* * p=0.158$ & \\
\hline
\end{tabular}

C:control animals, T: treated animals,1,2,3 are the period of scarifying animals /months

$\mathrm{P} \leq 0.05$ was considering significant, $\mathrm{P}$ for value versus control, ${ }^{*} p$ for versus between $\mathrm{T} 1, \mathrm{~T} 2$,

${ }^{* *} p$ for versus between $\mathrm{T} 2, \mathrm{~T} 3$. 


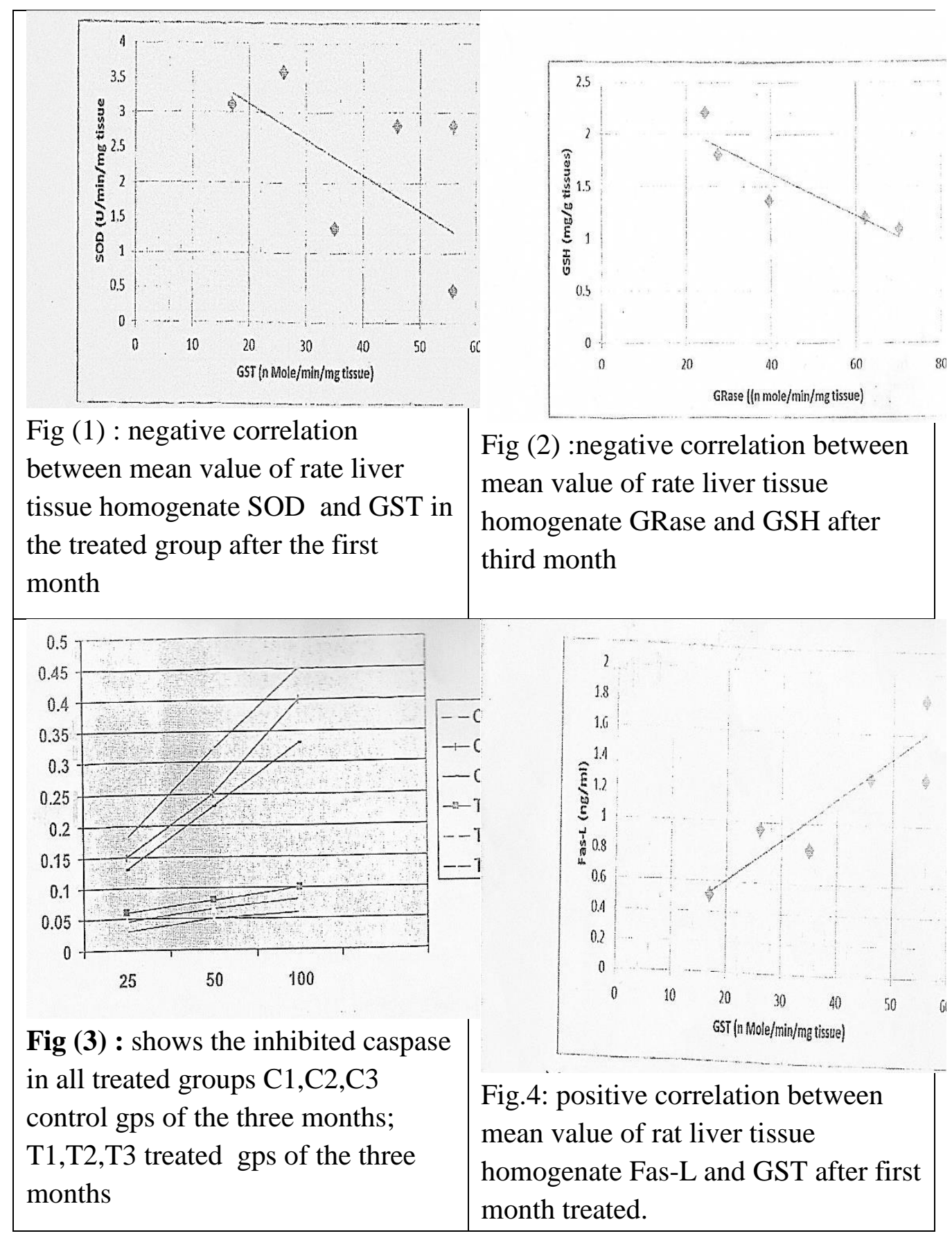

Bulletin of the National Nutrition Institute of the Arab Republic of Egypt. June 2018 (51) 16 


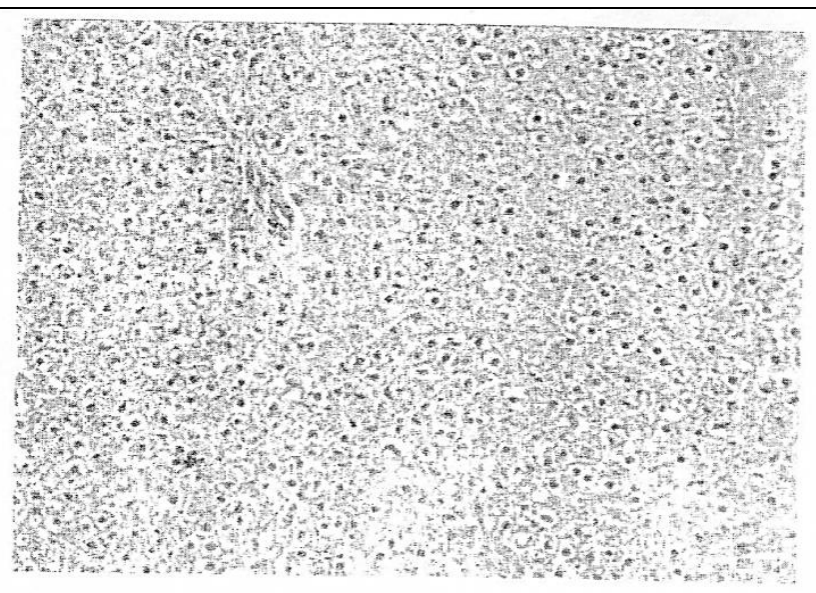

Fig .5: a photograph of control group of liver (H\& E 100). Showed normal architecture pattern of liver cells

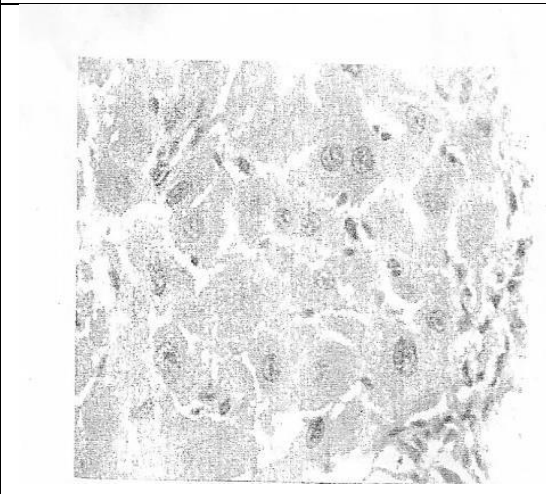

Fig.6: a photograph of treated group at second month represented by fatty degenerate hepatitis grade 11 no evidence of malignancy or cirrhosis.

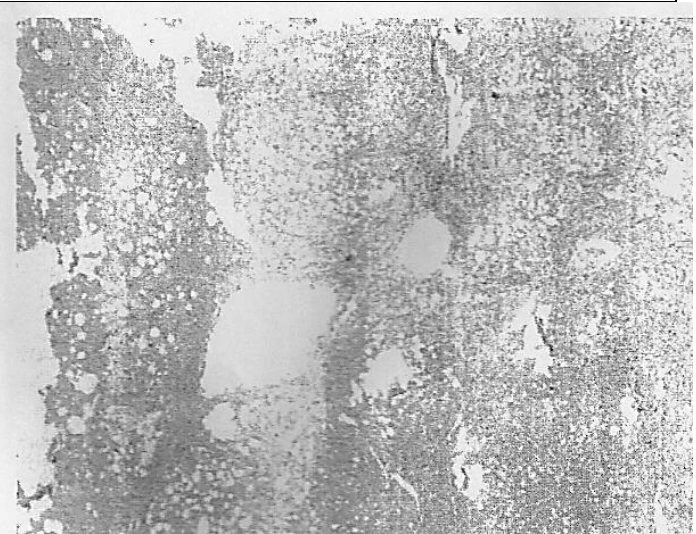

Fig.7: a photograph of the third month treated of rat liver homogenate (H\&E 100). The normal hepatic architecture is replaced totally by cirrohotic nodules with intervening chronic inflammatory infiltrate grade 111, some foci at the peripheral show invasive trabecula of moderately differentiating hepatocytes amounting grade $1 \mathrm{HCC}$. 


\section{تقدير بروتينات الفاس و الكسباز ودورهما في نقل الاشارة المتسلسلة في

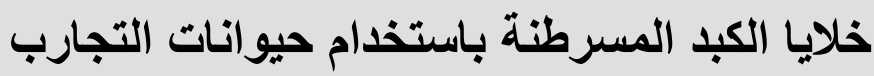 \\ سها محمد حمدي، سعد محمد الجندي ، سحر سيد عتريس كلية العلوم - قسم الكيمياء - جامعة الفيوم الملخص العربي}

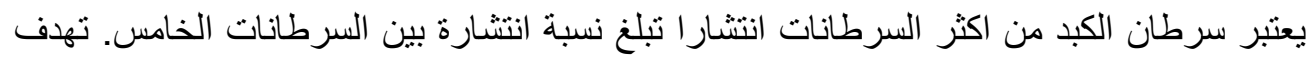

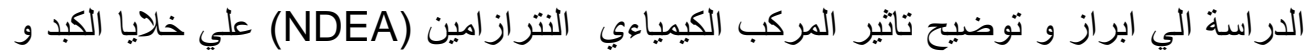

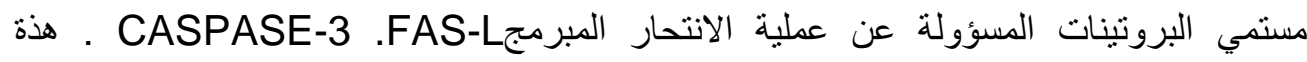

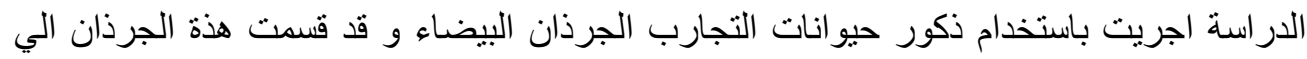

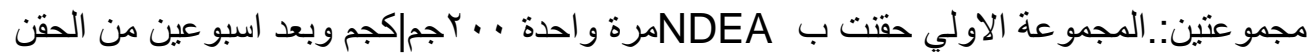

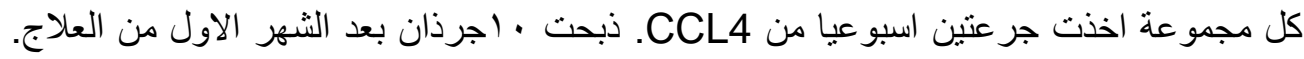

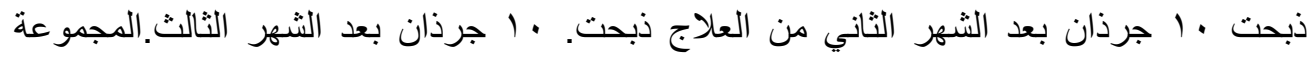

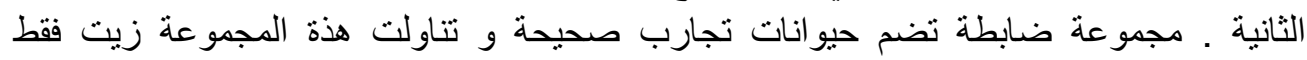

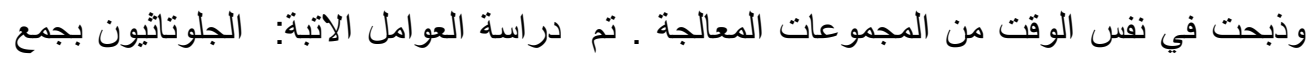

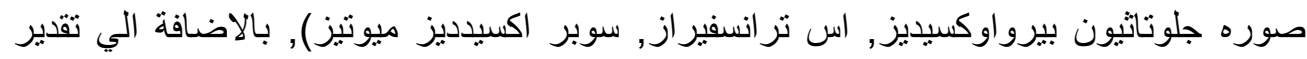

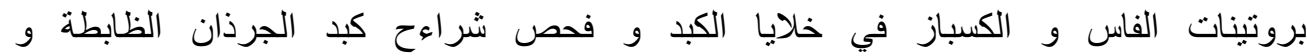
المعالجة.واوضحت نتائج هذة الدراسة نقص في مستوي الانزيمات المضادة فئاد للاكسدة خلال الثلاث

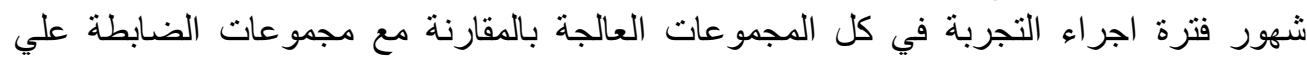

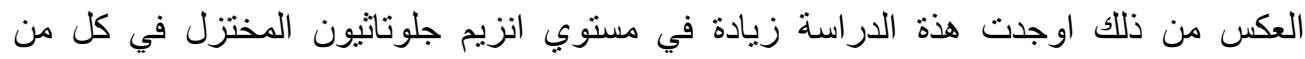

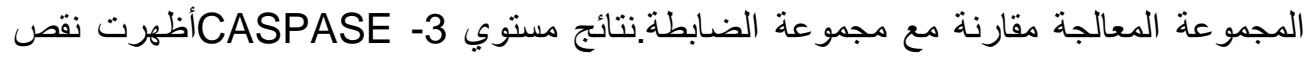

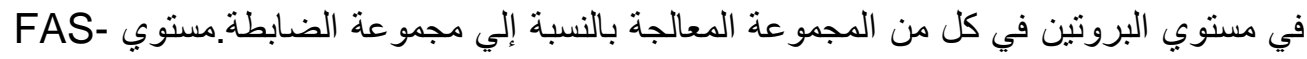

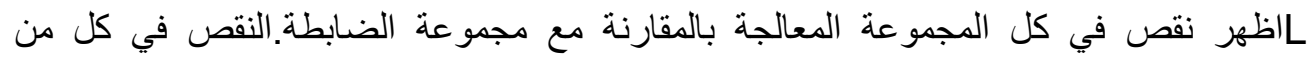

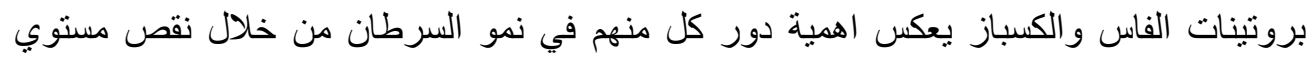

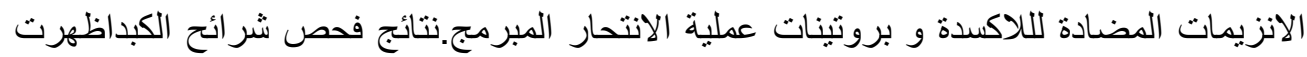

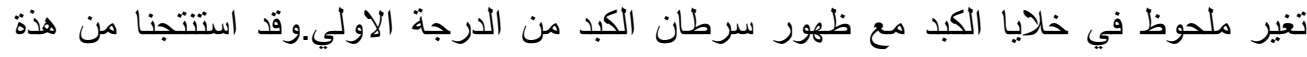

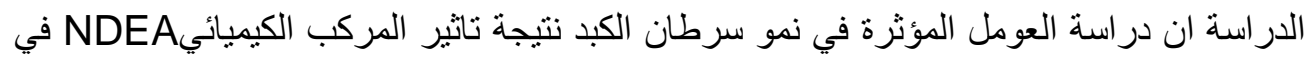

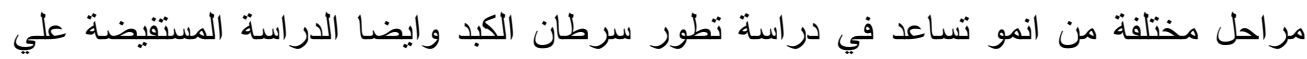

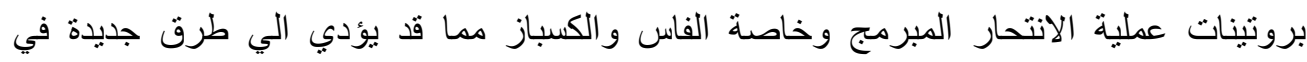
العلاج.

الكلمات المفتاحية: بروتينات الفاس و الكسباز - سرطان الكبد 